\title{
Should the Fed Have a Financial Stability Mandate? Lessons from the Fed's first 100 Years
}

Renee Haltom and Jeffrey M. Lacker

$\mathrm{T}$ he year 2013 marked the 100th anniversary of the Federal Reserve Act that created the Fed. The Act was passed to address recurrent financial crises, so it is ironic that the Fed's centennial nearly coincided with the global financial crisis of 2007-08, the worst financial crisis in generations.

Federal Reserve lending programs were prominent during the crisis, and the Fed supervised important parts of the financial sector prior to the crisis. Understandably, many policymakers and academics have been asking whether changes to the Fed's responsibilities and authorities are needed to create a more stable financial system.

But what should the Fed's role in financial stability be?

The broad context for this question is the movement in the global central banking community toward more formal financial stability mandates. ${ }^{1}$ These efforts have tended to focus on prevention, namely looking for signs of excessive risk-taking in an array of financial markets. In the United States, the 2010 Dodd-Frank Wall Street Reform and Consumer Protection Act enhanced the Fed's surveillance powers and imposed new constraints on risk-taking in the financial sector, all aimed at reducing the probability of the type of financial market turmoil

- Renee Haltom is research publications content manager, and Jeffrey M. Lacker is president of the Federal Reserve Bank of Richmond. The authors would like to thank Huberto Ennis, Robert Hetzel, and John Weinberg for valuable feedback and insight. The views expressed are those of the authors and not necessarily those of the Federal Reserve Bank of Richmond or the Federal Reserve System.

DOI: http://doi.org/10.21144/eq1010104

${ }^{1}$ For a summary, see Bank for International Settlements (2011). 
experienced during the recent crisis. $^{2}$ One implication of heightened responsibility for financial stability is that a central bank should use all the tools at its disposal to mitigate identified problems, for example, by curtailing risk through targeted regulatory interventions, or even using monetary policy tools to prevent the negative effects that financial distress could have on central banks' objectives for growth and inflation.

Many of the Fed's past actions in the name of financial stability, however, have come in the form of credit extension once crises are underway, as in the case of the Fed's extraordinary lending to firms and markets in 2007 and 2008. A financial stability mandate would seem to imply a central bank obligation to intervene to alleviate potential damage in cases of financial distress.

Is crisis lending necessary for a stable financial system? Some observers have addressed this question by looking to the history of the Federal Reserve. The 1913 legislation creating the Fed grew out of the reaction to the Panic of 1907, an economic contraction in which many banks experienced runs and suspended depositor withdrawals. One central purpose of the Fed was to respond to such panics, which has been said to justify the broad range of Fed responses to modern financial crises.

Another common rationale for the Fed's emergency lending is the doctrine that a central bank should act as a "lender of last resort," an idea associated with the writings of Walter Bagehot, the 19th century British economist. Episodes in which the Fed failed to act aggressively as lender of last resort-most notably during the wave of bank failures at the outset of the Great Depression, which the Fed did little to prevent - are often described as demonstrating the necessity of crisis lending by the central bank.

This essay argues that these justifications for Fed crisis lending are based on erroneous readings of history. The Fed was originally designed and built to solve a monetary problem, not a lending problem. That monetary problem resulted from legislative restrictions that hindered the banking system's ability to issue currency and redistribute it as needed. Bagehot's 19th century work, too, was intended to encourage the Bank of England to provide liquidity to illiquid but otherwise

\footnotetext{
${ }^{2}$ There is clear support for a formal financial stability mandate in the United States. A near-final version of the 2010 Dodd-Frank Act almost took this step, stating that, "The Board of Governors shall identify, measure, monitor, and mitigate risks to the financial stability of the United States." For unexplained reasons, the phrase was dropped in conference. Some parties have even argued that a financial stability mandate already exists by virtue of the Fed's other mandates. For example, see Bank for International Settlements (2011), Dudley (2013b), Baxter (2013), and Tarullo (2012).
} 
Haltom and Lacker: Should the Fed Have a Financial Stability Mandate?51

solvent firms during panics. While this may sound similar to the Fed's actions in 2007 and 2008, Bagehot's prescriptions had more to do with providing monetary stability to the financial system as a whole in the face of panics than allocating credit to targeted sectors or firms as the Fed did during the recent crisis. The Great Depression can be misread as well. The Fed's central failing was that it allowed the money supply to fall precipitously, not that it didn't prevent bank failures.

By contrast, when the Fed has used its lending tools to promote financial stability by limiting creditor losses, the results have been less than salutary. In a series of incidents beginning in the 1970s, the Fed, in cooperation with the Federal Deposit Insurance Corporation, intervened to limit bank failures' effect on creditors. Early interventions were relatively small, but they established precedents that led potential creditors to expect to be rescued in future instances of financial distress, weakening their incentives to limit borrower risk-taking and vulnerability.

Government-lending programs often appeared to stabilize markets because they confirmed hopes of intervention, and so have been hailed as successes. ${ }^{3}$ But this has come at the cost of moral hazard, greater risk-taking, and greater instability down the road.

Tougher regulations may seem like a way to overcome the moral hazard that results from the government's safety net, but that strategy has fallen short in the past. Regulations can be helpful in containing risk, but they are fallible and boost the incentive to move risk-taking outside of regulated sectors. Moreover, a mandate for the central bank to prevent excessive risk-taking is likely to give rise to expectations that it will respond if it fails in that objective by ameliorating the effects with crisis lending. The implied government safety net then encourages riskier behavior. When the government steps in to protect creditors with emergency lending, it continues the self-perpetuating cycle of crisis, intervention, regulation, and regulatory bypass.

The result has been an ever-expanding government safety net and an ever-expanding interpretation of the Fed's role in financial stability.

Recent regulatory reforms continue our journey down this path. While the Dodd-Frank Act tried to improve the handling of large failing financial institutions, the capacity to use government resources to protect creditors remains. Instances of financial distress are inevitable, but the anticipation of support is likely to turn them into crises, eliciting ever-more rescues and preventative regulation. A broad and ill-defined financial stability mandate for the Fed would contribute to the cycle of

\footnotetext{
${ }^{3}$ For a review of literature on the effectiveness of crisis lending programs, see Fleming (2012).
} 
crisis and intervention by fostering the expectation that the Fed will respond to financial instability with all the tools at its disposal, including lending to protect the creditors of large financial institutions.

There is a way to correct this course, however, and it requires clarifying the Fed's role in financial stability. We need to break the cycle by which expectations of intervention beget excessive risk-taking, which begets distress and further interventions. The real lesson of the

Fed's first 100 years is that the best contribution the Fed can make to financial stability is to pursue its monetary stability mandate faithfully and abstain from credit-market interventions that promote moral hazard. A careful look at the Fed's first 100 years sheds light on reforms that would truly help ensure financial stability.

\section{WHAT PROBLEM WERE THE FED'S FOUNDERS TRYING TO SOLVE?}

Today, the Fed's primary goals are to achieve low, stable inflation and healthy employment. But neither of these goals is why the Fed was created. The Fed's purpose in 1913 was to help the monetary and banking system overcome legislative flaws.

At times, the public would want to convert a substantial amount of its bank deposits into currency. The fundamental problem was that it was costly and cumbersome to increase the supply of currency for banks to meet the demands of depositors. The architects of the Federal

Reserve Act often stated that the source of the problem was twofold. ${ }^{4}$ First, currency was issued by banks, not the government, but all currency was required by the National Banking Acts of 1863 and 1864 to be backed by U.S. government bonds. To issue new currency, banks would have to acquire new bonds and wait for new notes to be printed and shipped by the Bureau of Engraving and Printing, the agency that still prints currency today. This cumbersome process meant the supply of currency could not expand quickly. ${ }^{5}$

Second, the banking system was fragmented. Most U.S. states prohibited banks from establishing branches. When the Fed was founded, there were more than 27,000 banks; virtually every town had its own. Other countries, such as Canada, had no branching restrictions, and this allowed banks to diversify their portfolios. In the United States, the health of many banks hinged on the local economy-often on the season's production of a single crop. Country banks kept deposits in

\footnotetext{
${ }^{4}$ For a review of literature on the effectiveness of crisis lending programs, see Fleming (2012).

${ }^{5}$ Cagan (1963)
} 
Haltom and Lacker: Should the Fed Have a Financial Stability Mandate?53

city "correspondent" banks, which in turn kept deposits in the major money center banks and clearinghouses that were mainly in New York. ${ }^{6}$ When currency demand surged, country banks would ask their correspondent banks for shipments of banknotes, to be paid for from their reserve accounts. But sometimes the demands on the money center institutions were too great, and they refused withdrawal requests to preserve cash for themselves. This resulted in suspensions of payments to depositors, who rushed to be first in line when suspension or failure was feared, resulting in "bank runs." A run on one institution sometimes led to runs on others, resulting in what were known as broader "financial panics."

These two problems had serious consequences. The pressure on the currency supply during the autumn harvest season meant interest rates were significantly higher in the fall than the rest of the year, the equivalent today of the Fed significantly tightening monetary policy every Thanksgiving. ${ }^{7}$ Bank panics could be devastating to economic activity because they disrupted the ability to make payments conveniently. Carter Glass, the senator from Lynchburg, Va., who helped design the Federal Reserve, said that panics, "affected not alone the financial institutions immediately involved, but the merchants whose credits were suspended; the industries whose shops were closed; the railroads whose cars were made idle; the farmers whose crops rotted in the fields; the laborer who was deprived of his wage. No business enterprise, if any individual, ever entirely escaped." 8 Prior to the Fed's founding, major panics occurred in 1873, 1884, 1890, 1893, and 1907, with many smaller panics and bank failures in between. It was that last particularly disastrous panic in 1907 that finally galvanized the political will - after more than three-quarters of a century without a central bank - to create the Fed.

Congressmen, bankers, and economists all participated in the debate over how to reform the banking system. Discussions centered on laws pertaining to currency. Who should issue it? What would back it? How would oversupply be prevented to preserve its value? Some factions wanted banks to issue currency against their own general assets, sidestepping frictions in the U.S. bond-backed system, but there was little agreement on how to prevent over-issue. Others wanted to broaden membership in the system of private clearinghouses that had averted

\footnotetext{
${ }^{6}$ Keeping deposits in other banks also facilitated check clearing in the days when physical checks traveled by horse and carriage. Reserves allowed "correspondent" banks to immediately cash each other's checks by drawing down the correspondent's reserve balance (Lacker, Walker, and Weinberg 1999).

7 Miron (1986)

${ }^{8}$ Glass $(1922,5-7)$
} 
panics in the late 1800s by pooling the reserves of members and issuing emergency credit. However, many vehemently opposed the accompanying centralization of institutional power. Dismantling restrictions on bank branching and consolidation was viewed as clearly desirable but politically infeasible since farmers and small bankers opposed it, and thus it received little attention. ${ }^{9}$ After considerable debate over the balance between centralized and regional powers, a federated system of regional Reserve Banks was adopted. The Federal Reserve Act was passed in 1913, and the Fed opened its doors in November 1914.

\section{WAS THE FED CREATED FOR FINANCIAL STABILITY?}

The preamble to the Act stated that the Fed was created to "furnish an elastic currency." This was to take place primarily through loans from the Fed to commercial banks. Banks facing a heightened short-term need for currency could obtain it from their regional Reserve Bank. In exchange, the banks would assign the Reserve Bank some of their own assets at a discount that reflected an implied interest rate - hence, the process was called "rediscounting" the bank's initial loan, and the Fed's lending was called the "discount window." 10

A crucial feature was that only a very specific, limited set of assets were eligible for rediscounting. The Federal Reserve Act reflected elements of "real bills," a doctrine dating to the early 18th century that held that banknotes should be backed exclusively by loans that funded legitimate commercial activity, as opposed to speculative investments. ${ }^{11}$ Currency issued via such lending would be retired naturally when the economy no longer needed it since the underlying loans would be repaid with the sale of goods and services. In the context of the original Federal Reserve Act, only short-term paper arising from

\footnotetext{
${ }^{9}$ Sprague (1910, 249-251); Glass (1922, 5); Calomiris (1990); Wicker (2005, 2-3). Alternatives to currency reform and the Fed were discussed but did not gain traction. In addition to bank branching, deposit insurance was considered, but large banks objected under the argument that it would force them to subsidize the risk-taking of small banks (Flood 1992). For more discussion on how the reform debate evolved prior to the Federal Reserve Act, see Wicker (2005), Warburg (1930, Chapter 1), and Willis (1923).

${ }^{10}$ To make the loan, the lending Reserve Bank would credit the borrowing bank's reserve account. The bank could then withdraw the reserves in the form of currency (Federal Reserve notes) if so desired.

${ }^{11}$ To be precise, the real bills doctrine said that if banks lent against only sound, short-term paper, the money supply would automatically match the needs of commerce. The doctrine has since been discredited for ignoring the fact that inflation would itself create a greater demand for currency to fund trade. See Humphrey (1982) for more discussion.
} 
Haltom and Lacker: Should the Fed Have a Financial Stability Mandate?55

commercial transactions or international trade was eligible for rediscounting. ${ }^{12}$

The Fed also was given authority to buy certain securities - assets eligible for rediscounting plus government debt - through open market operations. The intent of open market operations was to strengthen the Fed's ability to control gold flows, but it also provided another tool for expanding the supply of bank reserves and circulating notes, and it would become more important later in the Fed's history. ${ }^{13}$ Open market purchases were made by crediting banks' reserve accounts and had the same effect on the supply of monetary assets - Federal Reserve notes, reserve balances with Federal Reserve Banks, and gold coins and bullion - as discount window loans.

We would argue that the primary goal of the Fed's founders was to achieve monetary stability. "Furnishing an elastic currency" meant that the supply of monetary assets would vary with fluctuations in demand. Instead of interest rate spikes and withdrawal suspensions, swings in the need for currency could be accommodated smoothly and interest rate movements would be dampened. In recent decades, the Fed generally has managed the money supply through open market operations. Purchases and sales are designed to keep a short-term interest rate - the federal funds rate - at a target value set by the Federal Open Market Committee. ${ }^{14}$ Open market operations have been the main tool of monetary policy and have been used to manage the money supply to keep inflation low and stable.

In 1914, monetary policy was conducted through direct lending to banks. As a result, the distinction between monetary policy and credit allocation - when policymakers choose certain firms or markets to receive credit over others - was blurred in the language the founders often used. A careful reading of the debates over the Federal Reserve Act makes clear, however, that the only intended type of credit allocation was the one embodied in the real bills doctrine. Federal Reserve lending was to channel credit away from uses that would lead to

\footnotetext{
12 The Federal Reserve Act itself did not indicate that only "self-liquidating" loans were eligible, a defining component of real bills (Humphrey 1982). However, maturity limits were imposed, and the same month the Fed opened, the Board clarified in its accompanying regulations that notes funding permanent or fixed investments, like land and capital, were ineligible for rediscounting. That exclusion was lifted in 1973, though maturity limits remained (Hackley 1973, 35-37).

${ }^{13}$ If the Fed created an artificial shortage of reserves through asset sales, banks would be forced to borrow from the Fed at the discount rate, which would ensure its influence over other market rates, and therefore gold flows. Policymakers at the Fed disagreed over whether open market operations were contradictory to real bills (Meltzer 2003, 263-264).

${ }^{14}$ Hetzel (2004)
} 
"speculative excesses," such as call loans in the stock market, and toward more productive uses, such as the "needs of commerce."

The Fed has since abandoned the real bills doctrine, but the central bank has engaged in a different type of credit allocation: preventing losses for the creditors of specific distressed financial institutions or asset markets. This type of credit allocation is often conflated with the lending envisioned at the Fed's founding because the tools are the same. The original Federal Reserve Act was not wellsuited to this contemporary form of credit allocation, however. The Act significantly limited the Fed's ability to support many types of financial entities because only member banks had access to the Fed's discount window. Nonmember banks were excluded, as were many other types of financial institutions, including the trusts that were at the center of the Panic of 1907. Moreover, it would be surprising if the founders had included such provisions; they generally opposed guarantee schemes for fear they would encourage banks to take greater risks. ${ }^{15}$

Before the Fed's creation, panics were simply an acute manifestation of the broader monetary instability problem. With the latter perceived as solved by the Federal Reserve Act, the Fed's founders largely ignored the question of whether the new system would adequately prevent narrower instances of financial distress at individual banks. The hearings over the Glass-Owen bill that became the Federal Reserve Act featured almost no discussion of whether the legislation sufficiently prevented panics, the role of open market operations in providing backstop liquidity, and whether the legislation's restricted discount window access would impair the Fed's ability to avert crises. ${ }^{16}$ Moreover, the Act included no provision for relaxing lending standards to resolve panics. If firms couldn't obtain credit under the Fed's strict collateralization rules - in a panic or otherwise - then they were considered to be simply unworthy of credit.

All this indicates that the stabilizing role envisioned by the founders was to provide for the general circulation of currency, not to channel funds to targeted institutions or markets in crises. In other words, it is more accurate to say that the Fed was originally created and designed to ensure monetary stability, not financial stability as the latter term is now understood.

\footnotetext{
${ }^{15}$ Carter Glass, who coauthored the Glass-Owen bill that became the Federal Reserve Act, was a well-known opponent of deposit insurance. Federal deposit insurance was nonetheless incorporated into the Glass-Steagall Act of 1933 as an 11th-hour addition in exchange for the support of Alabama Rep. Henry Steagall for the bill's many other provisions that Glass advocated. Steagall represented many small banks that would be kept viable by deposit insurance in the face of increasing bank branching and consolidation (Flood 1992; Economides, Hubbard, and Palia 1996).

${ }^{16}$ Wicker $(2005,78)$
} 
Haltom and Lacker: Should the Fed Have a Financial Stability Mandate?57

\section{WHAT ABOUT BAGEHOT AND THE CENTRAL BANK AS THE LENDER OF LAST RESORT?}

If that's the case, then where did the notion of "lender of last resort" come from? The phrase is associated with Bagehot, the classical economist, who in 1873 refined the earlier work of Henry Thornton on the central bank of England. ${ }^{17}$ Bagehot's famous dictum on central bank lending in a crisis is often paraphrased as, "lend freely on good collateral at penalty interest rates." Many people have argued that this is what the Fed did during the recent financial crisis. ${ }^{18}$

Bagehot is often misinterpreted, though, because our current financial system is very different from the one he confronted. In those days, the central bank's loan to a bank necessarily increased the money supply; once again, direct lending and monetary policy were intertwined. Today, by contrast, direct lending and monetary policy are separate processes with separate objectives. Direct lending is conducted so as not to have any effect on the overall money supply. ${ }^{19}$ In Bagehot's time, central bank lending was simply the primary way the money stock was managed. What's more, the Bank of England's discount lending was intermediated through "discount houses," which effectively prevented the Bank from knowing the identities of the borrowing institutions, much less allocating credit based on case-by-case analysis of their financial conditions and interconnections within the financial system. ${ }^{20}$ Thus, when Bagehot advocated central bank lending in a crisis, he was advocating that the central bank expand the money supply to meet the increase in demand. ${ }^{21}$

Moreover, Bagehot advocated crisis lending only under a specific set of rules - only against good collateral and at above-market interest rates to dissuade firms from relying on central bank credit as a substitute for risk management. Bagehot further advised the central bank to allow insolvent firms to fail if they could not meet those terms, even if their failures might shake market confidence, because the expectation of bailouts would only encourage risk-taking and "rashness." If failures threaten to hurt other firms or the economy at large, Bagehot said

\footnotetext{
${ }^{17}$ Thornton and Bagehot never actually used the phrase "lender of last resort." The first popular English usage was in 1932 in Art of Central Banking by R.G. Hawtrey, although Sir Francis Baring in 1797 did refer to the Bank of England as "the dernier resort," a source of liquidity for banks in a crisis (Humphrey 1989).

${ }^{18}$ For example, see Madigan (2009) and Wolf (2014).

${ }^{19}$ Discount window loans increase the supply of bank reserves, and in normal times are offset to prevent downward pressures on the federal funds rate, the FOMC's targeted interest rate.

${ }^{20}$ Capie $(2002,311)$

${ }^{21}$ Goodfriend and King (1988)
} 
the central bank should continue to protect the money stock through liberal lending without relaxing its criteria. And importantly, he said, the central bank should make these policies clear ahead of time to reassure the public that currency will be available and to prevent firms from expecting a central bank safety net to protect them from bad investments. $^{22}$

The context in which Bagehot wrote is often omitted from modern invocations. Bagehot began work on his famous book Lombard Street in the autumn of 1870, during the Franco-Prussian War. The French central bank already had suspended payments, a move that threatened to heighten gold demands on the Bank of England. Bagehot felt the Bank of England needed to maintain a large stock of gold to reassure markets that the currency supply would be protected. In fact, much of Lombard Street was about that need, not panics. ${ }^{23}$ However, he wrote, if the large gold stock wasn't enough to allay panic, the Bank of England should follow the "brave plan" and lend liberally. Such lending would be "brave" because the Bank of England was set up to be accountable to stockholders, so the profit motive made it naturally reluctant to lend in riskier times. Bagehot's dictum to "lend freely at a penalty rate" was intended to encourage a risk-averse Bank of England to lend.

The Fed faces the opposite dilemma because it lends taxpayer dollars. The Fed receives no appropriations from Congress, but it remits all profits in excess of operational costs to the U.S. Treasury, so taxpayers bear both profit and losses from the Fed's investments. The challenge for the Fed is how to resist the temptation - and perhaps political pressure - to over-lend. ${ }^{24}$ Singling out Bagehot's dictum about crises glosses over his emphasis on protecting the overall money stock in both normal and crisis times and his vigilance regarding moral hazard.

The Fed's lending during the 2007-08 financial crisis bore little resemblance to what Bagehot had in mind. First, it was not monetary in nature. For most of the crisis, the Fed ensured that its unusual lending had no monetary impact by sterilizing the effects on the money supply (that is, simultaneously selling an equivalent amount in Treasury securities). In fact, until interest rates were effectively reduced to zero in late 2008, the Fed's interest rate targeting procedures made the supply of monetary assets vary automatically with movements in demand, without the need for special lending. When the Fed's balance sheet did grow in late 2008, it was primarily a byproduct of its targeted lending

\footnotetext{
${ }^{22}$ Goodfriend and King (1988)

${ }^{23}$ Rockoff (1986)

${ }^{24}$ This point is argued by Goodfriend (2012).
} 
Haltom and Lacker: Should the Fed Have a Financial Stability Mandate?59

to support the flow of credit to particular markets, notably mortgage markets; it did not emerge primarily from a desire to ease monetary conditions. ${ }^{25}$ Much of the Fed's crisis response was openly about allocating credit to specific sectors and institutions perceived as being in trouble, not about managing the money supply.

The Fed's crisis response departed from Bagehot's recommendations in other ways as well. The Fed provided financing in connection with two arguably failing institutions, Bear Stearns and American International Group. The Fed protected countless other creditors through emergency lending to support asset prices. No pre-announced policy governing intervention was articulated or followed. The Fed failed to charge penalty interest rates in some cases and took on credit risk by accepting troubled and difficult-to-value securities as collateral. ${ }^{26}$

Bagehot and the traditional conception of a lender of last resort thus provide scant support for the interventions that the Fed undertook in the name of financial stability during the recent crisis.

\section{WOULD FAILURE TO LEND HAVE CAUSED ANOTHER GREAT DEPRESSION?}

Advocates of strong central bank actions to promote financial stability often cite the Great Depression, when the Fed reacted passively, allowing a third of the nation's banks to fail between 1930 and the banking holiday of 1933. The Fed's policy failure at the outset of the Depression was a principal finding of Milton Friedman and Anna Schwartz in their famous 1963 book, A Monetary History of the United States. It prompted Ben Bernanke, himself a scholar of the Depression, to tell Friedman and Schwartz in 2002, "You're right, we did it. We're very sorry. But thanks to you, we won't do it again." The Fed has never repeated the mistake.

In the 1930s, the Fed could have lent to prevent bank failures but did not. In part, this reluctance reflected the real bills doctrine, which, under the circumstances, encouraged Reserve Banks to be overly conservative. $^{27}$

Reserve Banks also resisted conducting open market purchases because that would drive down interest rates and lead to gold outflows,

\footnotetext{
${ }^{25}$ In an October 2009 speech, then-Chairman Ben Bernanke said, "Although the Federal Reserve's approach ... entails substantial increases in bank liquidity, it is motivated less by the desire to increase the liabilities of the Federal Reserve than by the need to address dysfunction in specific credit markets. ... For lack of a better term, I have called this approach "credit easing."'

${ }^{26}$ Madigan (2009); GAO (2013b); Goodfriend (2012).

${ }^{27}$ Richardson and Troost (2009)
} 
jeopardizing their ability to defend the gold standard. ${ }^{28}$ The money supply contracted by a third from 1929 to 1933, with a commensurate fall in the overall price level. Friedman and Schwartz emphasized the devastating impact of this dramatic and unanticipated deflation. Loan defaults rose as borrowers struggled to acquire the dollars they needed to repay debts.

Bank failures were less important than the collapse of the money supply. For example, Canada had zero bank runs or failures during the same time period, but it also had a severe depression after its money supply declined by 13 percent. ${ }^{29}$ To be sure, bank failures hastened withdrawals and reduced deposits, worsening the money supply decline. But the Fed could have offset that by increasing bank reserves through open market operations. Indeed, the contraction slowed when open market operations were conducted in the spring of 1932, and the contraction resumed when the Fed reversed course later that year. ${ }^{30}$ Friedman and Schwartz concluded that, "If [failures] had occurred to precisely the same extent without producing a drastic decline in the stock of money, they would have been notable but not crucial. If they had not occurred, but a correspondingly sharp decline had been produced in the stock of money by some other means, the contraction would have been at least equally severe and probably even more so." ${ }^{31}$

The lesson, then, is that central banks should prevent deflation, not necessarily bank failures. The Great Depression was a failure of monetary stability, not financial stability.

\section{WHY IS TOO MUCH LENDING RISKY?}

After 1951, the Fed shifted the purpose of the discount window from being a tool for monetary policy to primarily one for allocating credit to specific firms. ${ }^{32}$ A 1968 Fed report noted that borrowing averaged less than 2 percent of total Fed credit extended from the 1930s to the mid1960s. ${ }^{33}$ The report explicitly adopted, seemingly for the first time, the role of lender of last resort "when liquidity pressures threaten to engulf whole classes of financial institutions." Though the report emphasized that the Fed's function is not to provide a "bail-out operation," it

\footnotetext{
${ }^{28}$ Eichengreen (1992)

${ }^{29}$ Friedman and Schwartz (1963, 352)

${ }^{30}$ See essays about the Great Depression era on federalreservehistory.org.

${ }^{31}$ Friedman and Schwartz $(1963,352)$

${ }^{32}$ Hackley (1973, 185-188)

${ }^{33}$ Board of Governors (1968)
} 
Haltom and Lacker: Should the Fed Have a Financial Stability Mandate?61

provided great detail on how existing laws might enable the Fed to extend credit to nonmembers and nonbanks in emergencies.

The report was prescient because the Fed was called to perform this function within two short years. In a series of incidents, the Fed and other regulators began intervening in ways that rescued the creditors of large, distressed financial firms. After the Penn Central railroad defaulted on $\$ 82$ million in paper obligations in 1970, the Fed indirectly supported securities markets by encouraging banks to borrow from the Fed to purchase commercial paper. In 1972 , the FDIC gave the $\$ 1.2$ billion Bank of the Commonwealth a $\$ 60$ million line of credit that prevented its failure after rising interest rates produced significant losses on municipal debt. After escalating losses in 1974, the Fed lent $\$ 1.7$ billion to Franklin National Bank, accepted deposits from its foreign branch as collateral, and assumed $\$ 725$ million of its foreign exchange book. When the $\$ 40$ billion bank Continental Illinois was pulled under by bad loans in 1984, it was able to borrow from the discount window even as it was receiving a capital injection from the FDIC. The FDIC committed to guaranteeing deposits even above the statutory limit of $\$ 100,000$, and it gave the bank and its parent company a permanent capital infusion. ${ }^{34}$

These were among the largest examples of government rescues, but there were many others. From 1985 through 1991, 530 discount window borrowers failed within three years of borrowing from the Fed; 437 of them had the lowest possible examiner rating, and 60 percent of them had outstanding discount window loans when they failed. ${ }^{35}$

The Fed and the FDIC operated in concert. Fed lending bought time for the FDIC to arrange for the institutions to be sold or kept afloat with FDIC funds. Fed lending also provided time for uninsured creditors - that is, those who had not been explicitly promised support before the trouble began - to exit without losses, increasing the cost of the failure to the FDIC. Between 1986 and 1991, the average size of troubled banks that the FDIC liquidated without protection of uninsured creditors was $\$ 65$ million, while the average size of banks whose uninsured creditors were protected was $\$ 200$ million. $^{36}$

In the most well-known cases, the government's stated concern was not the welfare of a single institution's creditors, but the possibility that, if the institution failed, funding costs would rise for other market (2013).

${ }^{34}$ For more on these episodes, see Sprague (1986) and Carlson and Wheelock

${ }^{35}$ Schwartz (1992). The appendix in Sprague (1986) lists the 100 largest banks that received FDIC assistance from the Depression through 1985. Continental Illinois and Franklin National were ranked first and fourth, respectively.

${ }^{36}$ FDIC (1997) 
participants. ${ }^{37}$ In each case, the government intervened rather than test the market's ability to weather spillovers, and these actions successfully quelled the immediate volatility. Note that government intervention was unlikely to prevent knowledge from spreading about a given firm's trouble. The primary spillover that was affected was the inference investors drew about the government's willingness to intervene to support other market participants.

A strong case can be made that these interventions caused greater instability down the road. When the government defines in advance institutions that have access to its liquidity, it can tax and regulate those firms accordingly, offsetting moral hazard and constraining risktaking. By contrast, when the government suddenly expands its safety net in the face of threats to firms and markets that have not been taxed and regulated, or when it prolongs the life of insolvent firms, it conveys that market participants can take excessive risks without bearing the full costs. On the margin, funding flows to markets that seem most likely to receive government support. The expectation of that support reduces the monitoring efforts of creditors, so those borrowers can take greater risks. When firms fail, government support is invoked again.

As this narrative suggests, failures and the safety net have grown successively larger. Richmond Fed researchers calculate that, by 1999, approximately 45 percent of the financial sector was either explicitly protected by the government, or investors could reasonably expect protection because of past statements and actions. The protected portion rose to as much as 57 percent after the government's activities during the financial crisis. ${ }^{38}$ The size of the safety net suggests that moral hazard is a significant presence in our financial system.

\section{IS EMERGENCY LENDING NECESSARY?}

Our current financial system has changed dramatically over the past century. Banks and trusts dominated the landscape in 1913. The system now includes an interconnected web of banks and investment companies, including mutual funds, private equity pools, hedge funds, and others. These institutions operate with opaque interconnections and on a global scale, and they ultimately fund the bulk of economic activity. ${ }^{39}$

\footnotetext{
${ }^{37}$ Sprague (1986) provides detailed insight on the internal discussions that took place among regulators in these instances. The Fed was, more often than not, in complete support. Sprague notes, "What were the real reasons for doing the [bailouts]? Simply put, we were afraid not to."

${ }^{38}$ Marshall, Pellerin, and Walter (2013)

${ }^{39}$ Pozsar, Adrian, Ashcraft, and Boesky (2010)
} 
Haltom and Lacker: Should the Fed Have a Financial Stability Mandate?63

They use an array of complex financial instruments, and some perform bank-like functions in the sense that they accept very short-term instruments that function much like "deposits," and use them to fund longer-term investments.

A common argument given for preserving the Fed's emergency lending powers, despite the risks described above, is that the government must retain some way to provide backstop financial assistance to treat the fragilities inherent in banking. ${ }^{40}$ The essence of the financial crisis, in this view, was that many investors declined to roll over short-term, deposit-like investments in a process resembling a bank run. As the shadow banking system emerged over the past century, no official institution emerged to create an "elastic currency" for it - that is, a reliable supply of short-term credit instruments to fund the shadow banking system. ${ }^{41}$ In this narrative, the Fed's special lending programs during the financial crisis of 2007-08 simply provided an elastic currency to protect the needs of commerce. Many observers have described the crisis as a classic banking panic. ${ }^{42}$

If the fragility we recently observed were due mostly to inherent fragilities in banking, we should expect to see similar financial crises with some consistency across countries over time. Yet history shows that the occurrence of financial crises is very unevenly distributed. They were particularly prevalent during some periods but noticeably less frequent in others. The 1920s and 1930s, for example, and the period since 1973 have seen significantly more frequent crises than the classical gold standard period or the Bretton Woods era. ${ }^{43}$ And many countries have experienced far fewer crises than the United States, a fact documented in studies by Michael Bordo and Barry Eichengreen, Carmen Reinhart and Kenneth Rogoff, and Charles Calomiris and Stephen Haber.

Canada provides a particularly compelling example of a country that is quite similar to the United States but has avoided systemic banking panics altogether since 1839, despite the lack of a central bank until the mid-1930s. In the late 19th century, Canada allowed bank branching and less-restrictive issuing of banknotes, which made their banking system better able to respond to regional economic shocks. These features afforded Canadian banks an "elastic currency" with no central bank. If needed, Canadian banks could shift reserves between

\footnotetext{
${ }^{40}$ Dudley (2013a)

${ }^{41}$ Gorton (2010); Gorton and Metrick (2013)

42 See Bernanke (2013b), Gorton (2010), and the Federal Open Market Committee meeting transcripts from 2008, among others.

${ }^{43}$ Bordo, Eichengreen, Klingebiel, and Martinez-Peria (2001)
} 
them, and the confidence that this would take place seemed sufficient to ward off runs. The system was concentrated enough that banks could monitor each other's operations to offset the moral hazard that might otherwise arise from this private backstop. ${ }^{44}$

One reason we may not see crises consistently is that financial institutions face a different set of incentives across countries and time periods to fund themselves with short-term debt. There are alternative funding methods that aren't as vulnerable to sudden demands for withdrawals. If financial institutions choose to fund themselves with short-term, demandable debt, they can include provisions that make them more resilient, therefore reducing the incentive for runs. ${ }^{45}$ Many of these safeguards already exist: contracts often include limits on risktaking, requirements for borrowers to maintain a degree of liquidity, overcollateralization, and other mechanisms. ${ }^{46}$ Moreover, contractual provisions can explicitly limit investors' ability to flee suddenly, for example, by requiring advance notice of withdrawals or allowing borrowers to restrict investor liquidations. Indeed, many financial entities outside the banking sector, such as hedge funds, avoided financial stress by adopting such measures prior to the crisis. ${ }^{47}$

Yet, leading up to the crisis, many financial institutions chose funding structures that left them vulnerable to sudden mass withdrawals. Why? Precedents established over the previous four decades arguably convinced market participants of an implicit government commitment to provide liquidity in the event of significant financial distress. Larger bank holding companies relied to a greater extent on the short-term credit markets that ended up receiving government support during the crisis. ${ }^{48}$ As the crisis unfolded, beginning in the summer of 2007, the Federal Reserve took actions that are likely to have further influenced expectations regarding support. In August 2007, the Fed lowered the discount rate and urged banks not to think of borrowing as a sign of weakness. In December 2007, the Fed implemented the Term Auction Facility in order to make credit available on more favorable terms.

The effect of these policy decisions is often underappreciated. They likely dampened the willingness of troubled institutions, such as Bear Stearns and Lehman Brothers, to undertake costly actions to shore up their positions, whether by raising capital, selling assets, or reducing their reliance on short-term funding. These incentives were further

\footnotetext{
${ }^{44}$ Bordo, Redish, and Rockoff (1996); Williamson (1989)

${ }^{45}$ Wallace (1988); Green and Lin (2003); Ennis and Keister (2010)

${ }^{46}$ Bernanke (2012)

${ }^{47}$ Aragon (2007); Zuckerman (2008)

${ }^{48}$ GAO (2013b)
} 
Haltom and Lacker: Should the Fed Have a Financial Stability Mandate?65

entrenched when the New York Fed funded JPMorgan's purchase of Bear Stearns in March 2008; for example, credit rating agencies considered the government's support of Bear Stearns in their decisions to leave Lehman Brothers with high ratings just before its collapse. ${ }^{49}$ When Lehman Brothers was allowed to fail in September 2008, despite being a much larger institution than Bear Stearns, these expectations were reevaluated suddenly, spurring the most volatile days of the financial crisis. Allowing Lehman to fail could have been the start of a new, more credible precedent against bailouts; but that same week, American International Group received assistance from the New York Fed, further confusing already volatile markets.

After decades of expanding the financial safety net, the precedents set during the crisis may have been the most consequential of all.

\section{IS THERE A BETTER PATH TO FINANCIAL STABILITY?}

The moral hazard that results from government support is not a new revelation. Dating back to the 1930s, policymakers have acknowledged it with virtually every step that expanded or reinterpreted the government's reach. ${ }^{50}$ From the Depression to the bank failures of the 1970 s and 1980s, major crises have prompted sweeping reforms to constrain risk-taking and prevent future financial distress. Yet, at each turn, policymakers have been unwilling to relinquish the ability to funnel credit to particular markets and firms in perceived emergencies. ${ }^{51}$ One can understand why, because such lending, by confirming hopes for intervention, appears to stabilize markets, as it did in 2007 and 2008. The approach instead has been to retain that power and attempt to counter moral hazard with enhanced supervision.

\footnotetext{
${ }^{49}$ In a September 2009 House subcommittee hearing, Moody's chairman and CEO Raymond McDaniel said, "An important part of our analysis was based on a review of governmental support that had been applied to Bear Stearns earlier in the year. Frankly, an important part of our analysis was that a line had been drawn under the number five firm in the market, and number four would likely be supported as well."

${ }^{50}$ Moral hazard was acknowledged during the debates surrounding deposit insurance (Flood 1992), the Board's apparent adoption of the lender of last resort role (Board 1968), the first time the Fed purchased mortgage-related securities in 1971 (Haltom and Sharp 2014), the bailouts of the 1970s and 1980s (Sprague 1986), and the actions during the financial crisis that motivated the Dodd-Frank Act-among other instances.

${ }^{51}$ A notable example was 1991's Federal Deposit Insurance Corporation Improvement Act. FDICIA limited the FDIC's ability to rescue firms and limited the Fed's ability to lend to insolvent ones. However, FDICIA loosened collateral requirements for the Fed's 13(3) emergency lending facility, granting what former Fed Chairman Alan Greenspan in 2010 called "virtually unlimited authority to the Board to lend in "unusual and exigent circumstances."
} 
The most recent crisis was no exception. The 2010 Dodd-Frank Act tightened limits on risk-taking and increased supervision, especially for "systemically important" financial firms. Title I of the Act allows regulators to constrain the activities of firms if their managements are unable to create a credible plan for their orderly wind-down in bankruptcy. Title II gives the FDIC authority to facilitate a firm's resolution if unassisted failure would threaten financial stability. Dodd-Frank prohibits the Fed from extending loans to specific firms under section 13(3) of the Federal Reserve Act, requiring instead that all 13(3) loans have "broadbased eligibility" and advance Treasury approval. The preamble to the Dodd-Frank Act states that one of its objectives is to end "too big to fail," the term often used to describe the government's historical tendency for bailouts of large, interconnected firms. ${ }^{52}$

Regulation, however, is far from foolproof as a way to counter moral hazard. To be sure, safety and soundness regulation is critically important given the size of the financial safety net. But regulations tend to take the current world as static, when in fact the world changes quickly, especially in response to new regulations. The emergence of the shadow banking system, for example, was a response to risk-taking limits imposed on traditional banks. Surveillance helps but may not keep up with innovation. In each past reform episode, policymakers have hoped they had their arms around risk-taking, and in the next episode, risk showed up in new places.

Thus, the real work of ensuring financial stability must start with addressing the incentives that encourage excessive risk-taking. DoddFrank does not accomplish this; like past reforms, policymakers retained broad discretion to conduct bailouts. ${ }^{53}$ An important difference between resolution authority under Dodd-Frank's Title II and the normal bankruptcy code is that the former gives the FDIC the ability to borrow from the Treasury to pay creditors of a failed firm, and it gives the FDIC broad discretion to determine which creditors to pay. ${ }^{54}$ Thus, creditors still can reasonably expect government support based on the government's past actions, with the attendant deleterious effects on their incentives to monitor a firm's activities. Moreover, Dodd-Frank's restrictions on 13(3) lending do not prevent bailouts. When large firms

\footnotetext{
52 The phrase "too big to fail" was made popular after the failure of Continental Illinois, when Comptroller of the Currency C.T. Conover explicitly stated that regulators were unlikely to allow the nation's 11 largest multinational banks to fail. Congressman Stewart McKinney responded, "let us not bandy words. We have [created] a new kind of bank. It is called too big to fail. TBTF, and it is a wonderful bank."

${ }^{53}$ Of too big to fail, Bernanke stated in a March 2013 press conference, "I never meant to imply that the problem was solved and gone. It is not solved and gone; it's still here ..."

${ }^{54}$ Pellerin and Walter (2012)
} 
Haltom and Lacker: Should the Fed Have a Financial Stability Mandate?67

are in trouble, it can be hard to distinguish between market distress and firm distress, and a broad-based lending program could be particularly attractive for a distressed firm.

At the same time, Dodd-Frank provides one of the most promising avenues for scaling back the perceived government backstop. Title I requires large firms to create "living wills," detailed plans for how each firms' operations could be rapidly wound down in an orderly manner under the U.S. bankruptcy code without government assistance. The Fed and the FDIC can jointly determine that a firm's proposed plan is not credible. In that case, if the firm does not revise the plan to regulators' satisfaction, they can impose changes to the firm's structure and operations that would make the firm resolvable without government assistance. Establishing credible living wills will be hard work. ${ }^{55}$ However, they currently provide the best hope for ending bailouts of "too big to fail" firms because they prompt regulators to create conditions under which they consistently prefer unassisted bankruptcy to bailouts. With a credible alternative to bailouts available, investors would have reason to expect that unassisted bankruptcy would be the norm, and firms would have a strong incentive to implement their own safeguards against runs.

In addition, certain reforms of the bankruptcy code could improve prospects for credible resolution plans. Currently, if a borrower files for bankruptcy, a provision of the code known as the "automatic stay" prevents creditors from seizing collateral or taking certain other actions against the borrower. The borrower's assets are essentially frozen until bankruptcy courts can oversee the development and adoption of a plan for the distribution of assets to creditors. Certain financial contracts, such as repurchase agreements and some derivatives, are exempt from this provision, and counterparties in such contracts are entitled to immediately liquidate their positions and seize collateral. Exemptions to the automatic stay were added to the bankruptcy code and enhanced in 2005 because it was felt that allowing derivatives counterparties to liquidate their positions immediately would reduce the incentive for lenders to run before bankruptcy is declared. The exemption creates instability in other ways, however. It reduces creditors' risk, and so distorts incentives toward greater use of exempted contracts, and diminishes the lender's incentive to monitor the firm. It presents the possibility of additional market volatility after a failure as lenders are liquidating their positions, and it can diminish the value of the failed firm, both of which make it more tempting for the government to rescue

\footnotetext{
${ }^{55}$ Lacker (2013b)
} 
large firms. ${ }^{56}$ Reforming the bankruptcy code to limit these exemptions would enhance stability. ${ }^{57}$

If expectations of government intervention were to persist, even with credible living wills and a better bankruptcy code, market participants would face dampened incentive to avoid fragile arrangements. Those expectations are likely to persist as long as there is the legislative authority to provide that support, such as the power to use the Orderly Liquidation Fund to protect creditors in a Title II FDIC resolution. This power will be unnecessary and obsolete once credible living wills are in place. At that point, repeal of Title II would enhance financial stability. The Fed still possesses expansive authority to conduct bailouts, however, since it can lend to various parties in the broader financial system without special congressional approval. Rescinding section 13(3) entirely would be a useful step toward establishing a credible commitment to resolve failing financial institutions without rescuing creditors. The same reasoning suggests imposing clearly articulated restrictions on discount window lending, strictly limiting it to good collateral at penalty interest rates, as Bagehot suggested. ${ }^{58}$

The steps outlined above won't eliminate instances of financial distress. But optimal financial stability does not mean the absence of financial firm failures and creditor losses. Indeed, a well-functioning financial system must allow firms to fail, even if they are large and interconnected. Financial stability is to be found in the financial system's resilience to potential triggering events - without government assistance. The steps described above may be our best chance at achieving true financial stability.

The Fed's emergency lending authority is anachronistic and unnecessary for the Fed's core mission of providing monetary stability. In a panic, open market operations are capable of flooding the market with liquid assets. For this reason, some economists have argued that the discount window is obsolete. ${ }^{59}$ Removing discretionary lending

\footnotetext{
${ }^{56}$ The Government Accountability Office notes that approximately 80 percent of Lehman's derivative counterparties terminated their contracts after the firm filed for bankruptcy, exacerbating Lehman's losses and leading to run-like behavior in money market mutual funds and other markets (GAO 2013a, 45-46).

${ }^{57}$ Roe (2011); Duffie and Skeel (2012)

${ }^{58}$ One example of an attempt to prevent government lending to insolvent firms is the "Prompt Corrective Action" provision of the Federal Deposit Insurance Act. PCA imposes increasingly aggressive restrictions on banks as their capital levels fall, although capital levels may not be sufficient as a measure of solvency because lags in the recognition of losses mean that the book value of capital is a backward-looking measure that can overstate the net worth of a bank. PCA has failed to limit the cost to the FDIC of failed banks, and regulators are considering changes (GAO 2011).

${ }^{59}$ See Goodfriend and King (1988); Schwartz (1992).
} 
Haltom and Lacker: Should the Fed Have a Financial Stability Mandate?69

authority would prevent future policymakers from feeling trapped into lending by the effects of expectations of support.

A critical lesson from the Fed's first 100 years is that an overly broad interpretation of the Fed's role in financial stability in fact undermines financial stability, contributing to a cycle of moral hazard, financial failures, and rescues. The Fed already has the tools and mandate it requires to provide monetary stability, which is its best contribution to financial stability.

REFERENCES

Aragon, George O. 2007. "Share Restrictions and Asset Pricing: Evidence from the Hedge Fund Industry." Journal of Financial Economics 83: 33-58.

Bagehot, Walter. 1873. Lombard Street: A Description of the Money Market. London: S. King and Co.

Bank for International Settlements. May 2011. "Central Bank Governance and Financial Stability." Study Group Report.

Baxter, Thomas C., Jr. November 15, 2013. "Financial Stability: The Role of the Federal Reserve System." Remarks at the Future of Banking Regulation and Supervision in the EU Conference, Frankfurt, Germany.

Bernanke, Ben S. November 8, 2002. "On Milton Friedman's Ninetieth Birthday." Remarks at the Conference to Honor Milton Friedman, University of Chicago, Chicago, Ill.

Bernanke, Ben S. October 8, 2009. "The Federal Reserve's Balance Sheet: An Update." Speech at the Federal Reserve Board Conference on Key Developments in Monetary Policy, Washington, D.C.

Bernanke, Ben S. April 3, 2012. "Some Reflections on the Crisis and the Policy Response." Speech at the Russell Sage Foundation and The Century Foundation Conference on "Rethinking Finance," New York, N.Y.

Bernanke, Ben S. March 20, 2013a. Transcript of Chairman Bernanke's Press Conference. Board of Governors of the Federal Reserve System, Washington, D.C. 
Bernanke, Ben S. November 8, 2013b. "The Crisis as a Classic Financial Panic." Speech at the Fourteenth Jacques Polak Annual Research Conference, Washington, D.C.

Board of Governors of the Federal Reserve System. 1968.

"Reappraisal of the Federal Reserve Discount Mechanism." Report of a System Committee.

Bordo, Michael D. January/February 1990. "The Lender of Last Resort: Alternative Views and Historical Experience." Federal Reserve Bank of Richmond Economic Review, 18-29.

Bordo, Michael D., and Barry Eichengreen. 2003. "Crises Now and Then: What Lessons from the Last Era of Financial Globalization." In Monetary History, Exchange Rates and Financial Markets: Essays in Honor of Charles Goodhart, Volume 2, edited by Paul Mizen. London: Edward Elgar Publisher, 52-91.

Bordo, Michael D., Barry Eichengreen, Daniela Klingebiel, and Maria Soledad Martinez-Peria. April 2001. "Is the Crisis Problem Becoming More Severe?" Economic Policy 16 (32): 51-82.

Bordo, Michael D., Angela Redish, and Hugh Rockoff. April 1996. "A Comparison of the Stability and Efficiency of the Canadian and American Banking Systems, 1870-1925." Financial History Review 3 (1): 49-68.

Bordo, Michael D., and David C. Wheelock. February 2011. "The Promise and Performance of the Federal Reserve as Lender of Last Resort 1914-1933." National Bureau of Economic Research Working Paper No. 16763.

Cagan, Phillip. 1963. "The First Fifty Years of the National Banking System." In Banking and Monetary Studies, edited by Deane Carson, 15-42. Homewood, Ill.: Richard D. Irwin.

Calomiris, Charles W. June 1990. "Is Deposit Insurance Necessary? A Historical Perspective." Journal of Economic History 50 (2): 283-95.

Calomiris, Charles W., and Stephen H. Haber. 2014. Fragile By Design. Princeton, N.J.: Princeton University Press.

Capie, Forrest. 2002. "The Emergence of the Bank of England as a Mature Central Bank." In The Political Economy of British Historical Experience 1688-1914, edited by Donald Winch and Patrick O’Brien, 295-315. London: Oxford University Press. 
Haltom and Lacker: Should the Fed Have a Financial Stability Mandate?71

Carlson, Mark A., and David C. Wheelock. February 2013 (Revised). "The Lender of Last Resort: Lessons from the Fed's First 100 Years." Federal Reserve Bank of St. Louis Working Paper Series No. 2012-056B.

Diamond, Douglas W., and Philip H. Dybvig. June 1983. "Bank Runs, Deposit Insurance, and Liquidity." Journal of Political Economy 91 (3): 401-19.

Dudley, William C. February 1, 2013a. "Fixing Wholesale Funding to Build a More Stable Financial System." Remarks at the New York Bankers Association's 2013 Annual Meeting \& Economic Forum, New York, N.Y.

Dudley, William C. June 23, 2013b. "Why Financial Stability is a Necessary Prerequisite for an Effective Monetary Policy." Remarks at the Andrew Crockett Memorial Lecture, Bank for International Settlements 2013 Annual General Meeting, Basel, Switzerland.

Duffie, Darrell, and David Skeel. 2012. "A Dialogue on the Costs and Benefits of Automatic Stays for Derivatives and Repurchase Agreements." In Bankruptcy Not Bailout: A Special Chapter 14, edited by Kenneth E. Scott and John B. Taylor. Stanford, Calif.: Hoover Institution Press.

Economides, Nicholas R., Glenn Hubbard, and Darius Palia. October 1996. "The Political Economy of Branching Restrictions and Deposit Insurance: A Model of Monopolistic Competition among Small and Large Banks." Journal of Law and Economics 39 (2): 667-704.

Eichengreen, Barry. 1992. Golden Fetters: The Gold Standard and the Great Depression, 1919-1939. New York: Oxford University Press.

Ennis, Huberto, and Todd Keister. First Quarter 2010. "On the Fundamental Reasons for Bank Fragility." Federal Reserve Bank of Richmond Economic Quarterly 96 (1): 33-58.

Federal Deposit Insurance Corporation. 1997. History of the Eighties, Lessons for the Future, Volume 1. Washington, D.C.: FDIC.

Fleming, Michael J. July 2012. "Federal Reserve Liquidity Provision During the Financial Crisis of 2007-2009." Federal Reserve Bank of New York Staff Report No. 563.

Flood, Mark D. July/August 1992. "The Great Deposit Insurance Debate." Federal Reserve Bank of St. Louis Review 74 (4): 51-77.

Friedman, Milton, and Anna Jacobson Schwartz. 1963. A Monetary History of the United States: 1867-1960. Princeton, N.J.: Princeton University Press. 
Glass, Carter. January 16-17, 1922. "Truth About the Federal Reserve System." Speech in the Senate of the United States, Washington, D.C.

Goodfriend, Marvin. November 2012. "The Elusive Promise of Independent Central Banking." Monetary and Economic Studies 30: $39-54$.

Goodfriend, Marvin, and Robert King. May/June 1988. "Financial Deregulation, Monetary Policy, and Central Banking." Federal Reserve Bank of Richmond Economic Review, 3-22.

Goodfriend, Marvin, and Jeffrey M. Lacker. Fall 1999. "Limited Commitment and Central Bank Lending." Federal Reserve Bank of Richmond Economic Quarterly 85 (4): 1-27.

Gorton, Gary B. 2010. Slapped in the Face By The Invisible Hand: The Panic of 200\%. Oxford, England: Oxford University Press.

Gorton, Gary B., and Andrew Metrick. Fall 2013. "The Federal Reserve and Panic Prevention: The Roles of Financial Regulation and Lender of Last Resort." Journal of Economic Perspectives 27 (4): 45-64.

Government Accountability Office. June 2011. "Modified Prompt Correction Action Framework Would Improve Effectiveness." GAO-11-612.

Government Accountability Office. January 2013a. "Financial Regulatory Reform: Financial Crisis Losses and Potential Impacts of the Dodd-Frank Act." GAO-13-180.

Government Accountability Office. November 2013b. "Government Support for Bank Holding Companies: Statutory Changes to Limit Future Support Are Not Yet Fully Implemented." GAO-14-18.

Green, Edward J., and Ping Lin. March 2003. "Implementing Efficient Allocations in a Model of Financial Intermediation." Journal of Economic Theory 109 (1): 1-23.

Greenspan, Alan. Spring 2010. "The Crisis.” Brookings Papers on Economic Activity, 201-61.

Hackley, Howard. 1973. Lending Functions of the Federal Reserve Banks: A History. Washington, D.C.: Board of Governors of the Federal Reserve System.

Haltom, Renee, and Robert Sharp. April 2014. "The First Time the Fed Bought GSE Debt." Federal Reserve Bank of Richmond Economic Brief. 
Haltom and Lacker: Should the Fed Have a Financial Stability Mandate?73

Hetzel, Robert L. Summer 2004. "How Do Central Banks Control Inflation?" Federal Reserve Bank of Richmond Economic Quarterly 90 (3): 47-63.

Humphrey, Thomas M. September/October 1982. "The Real Bills Doctrine." Federal Reserve Bank of Richmond Economic Review, $3-13$.

Humphrey, Thomas M. March/April 1989. "Lender of Last Resort: The Concept in History." Federal Reserve Bank of Richmond Economic Review, 8-16.

Inquiry into Continental Illinois Corp. and Continental Illinois National Bank: Hearings Before the Subcommittee on Financial Institutions Supervision, Regulation and Insurance, 98th Cong. (1984).

Lacker, Jeffrey M. February 12, 2013a. "Economics and the Federal Reserve After the Crisis." Speech to Franklin \& Marshall College, Lancaster, Pa.

Lacker, Jeffrey M. April 9, 2013b. "Ending 'Too Big To Fail' Is Going to Be Hard Work." Speech to the Global Society of Fellows Conference, University of Richmond, Richmond, Va.

Lacker, Jeffrey M. November 1, 2013c. "Global Interdependence and Central Banking." Speech to the Global Interdependence Center, The Union League of Philadelphia, Philadelphia, Pa.

Lacker, Jeffrey M., Jeffrey D. Walker, and John A. Weinberg. Spring 1999. "The Fed's Entry into Check Clearing Reconsidered." Federal Reserve Bank of Richmond Economic Quarterly 85 (2): $1-31$.

Madigan, Brian F. August 21, 2009. "Bagehot's Dictum in Practice: Formulating and Implementing Policies to Combat the Financial Crisis." Speech at the Federal Reserve Bank of Kansas City Economic Policy Symposium at Jackson Hole, Wyo.

Marshall, Elizabeth, Sabrina R. Pellerin, and John R. Walter. February 2013. "2013 Estimates of the Safety Net." www.richmondfed.org/publications/research/special_reports/safety_net.

Meltzer, Allan H. 2003. A History of the Federal Reserve, Volume 1: 1913-1951. Chicago: The University of Chicago Press.

Miron, Jeffrey A. March 1986. "Financial Panics, the Seasonality of the Nominal Interest Rate, and the Founding of the Fed." American Economic Review 76 (1): 125-40. 
Pellerin, Sabrina R., and John R. Walter. First Quarter 2012. "Orderly Liquidation Authority as an Alternative to Bankruptcy." Federal Reserve Bank of Richmond Economic Quarterly 98 (1): $1-31$.

Pozsar, Zoltan, Tobias Adrian, Adam Ashcraft, and Hayley Boesky. July 2010. "Shadow Banking." Federal Reserve Bank of New York Staff Report No. 458.

Reforming Credit Rating Agencies: Hearing Before the Subcommittee on Capital Markets, Insurance, and Government Sponsored Enterprises, 111th Cong. (2009).

Reinhart, Carmen M., and Kenneth S. Rogoff. 2009. This Time is Different. Princeton, N.J.: Princeton University Press.

Richardson, Gary, and William Troost. 2009. "Monetary Intervention Mitigated Banking Panics During the Great Depression: Quasi-Experimental Evidence from a Federal Reserve District Border, 1929-1933." Journal of Political Economy 117 (6): 1,031-73.

Rockoff, Hugh. 1986. "Walter Bagehot and the Theory of Central Banking." In Financial Crises and the World Banking System, edited by Forrest Capie and Geoffrey Wood, 160-180. New York: Macmillan.

Roe, Mark J. March 6, 2011. "The Derivatives Market's Payment Priorities as Financial Crisis Accelerator." Stanford Law Review 63 (3): 539-90.

Schwartz, Anna. September/October 1992. "Misuse of the Discount Window." Federal Reserve Bank of St. Louis Review 75 (5): 58-69.

Sprague, Irving H. 1986. Bailout: An Insider's Account of Bank Failures and Rescues. Washington D.C.: Beard Books.

Sprague, Oliver M.W. 1910. History of Crises Under the National Banking System. Washington D.C.: Government Printing Office.

Stein, Jeremy C. February 7, 2013. "Overheating in Credit Markets: Origins, Measurement, and Policy Responses." Speech to the "Restoring Household Financial Stability after the Great Recession: Why Household Balance Sheets Matter" Research Symposium, Federal Reserve Bank of St. Louis, St. Louis, Mo.

Tarullo, Daniel K. May 2, 2012. "Regulatory Reform Since the Financial Crisis." Remarks at the Council on Foreign Relations C. Peter McColough Series on International Economics, New York, N.Y. 
Haltom and Lacker: Should the Fed Have a Financial Stability Mandate?75

Thornton, Henry. 1802. An Enquiry into the Nature and Effects of the Paper Credit of Great Britain. London: Hatchard.

Wallace, Neil. Fall 1988. "Another Attempt to Explain an Illiquid Banking System: The Diamond and Dybvig Model with Sequential Service Taken Seriously." Federal Reserve Bank of Minneapolis Quarterly Review 12 (4): 3-16.

Warburg, Paul M. 1930. The Federal Reserve System: Its Origin and Growth: Volume One. New York: Macmillan.

Wicker, Elmus. 2005. The Great Debate on Banking Reform: Nelson Aldrich and the Origins of the Fed. Columbus, Ohio: Ohio State University Press.

Williamson, Stephen D. 1989. "Restrictions on Financial Intermediaries and Implications for aggregate Fluctuations: Canada and the United States 1870-1913." In NBER Macroeconomics Annual, Vol. 4, edited by Olivier Jean Blanchard and Stanley Fischer, 303-50. Cambridge, Mass.: MIT Press.

Willis, H. Parker. 1923. The Federal Reserve System: Legislation, Organization, and Operation. New York: Ronald Press Company.

Wolf, Martin. January 22, 2014. "Model of a Modern Central Banker." Financial Times.

Zuckerman, Gregory. April 10, 2008. "Hedge Funds Make It Hard to Say Goodbye." Wall Street Journal. 